\title{
Analysis Air Cooling Mechanism for Photovoltaic Panel by Solar Simulator
}

\author{
Y.M. Irwan ${ }^{1}$, W.Z. Leow ${ }^{2}$, M. Irwanto ${ }^{3}$, Fareq M M $^{4}$, A.R. Amelia ${ }^{5}$, N. Gomesh ${ }^{6}$, I. Safwati ${ }^{7}$ \\ ${ }_{1,2,3,4,5,6}$ Centre of Excellence for Renewable Energy, School of Electrical System Engineering, \\ University Malaysia Perlis (UniMAP), Malaysia \\ ${ }^{7}$ Institute of Engineering Mathematics, University Malaysia Perlis, (UniMAP), Malaysia
}

\begin{tabular}{l} 
Article Info \\
\hline Article history: \\
Received Jan 13, 2015 \\
Revised Apr 27, 2015 \\
Accepted May 10, 2015 \\
\hline Keyword: \\
Air cooling mechanism \\
Indoor Test \\
Power Output \\
Solar Simulator \\
Temperature
\end{tabular}

\begin{abstract}
Measurement the outdoor efficiency of photovoltaic (PV) panels is essential, but it is not likely an exceptional circumstance at any given moment is always repeating itself. A solar simulator was designed and fabricated for the purpose of analyzing the performance of PV panel with and without air cooling mechanism in indoor test. Twenty units of $500 \mathrm{~W}$ halogen lamps with build-in reflector support by the steel structure holder act as a natural sunlight. The requirement for a solar simulator is a stable solar radiation and illumination uniformity. The uniformity of the solar radiation was measured in the test area. Two units of PV panel with same characteristics were experimental in four sets of uniformity of solar radiation, which are 413, 620, 821 and $1016 \mathrm{~W} / \mathrm{m}^{2}$. The operating temperature of PV panel with air cooling mechanism can be decreased $2-3{ }^{\circ} \mathrm{C}$ compared to PV panel reference. The PV panel with air cooling mechanism can be increased in 6-14 \% of maximum power output based on different fixed of solar radiation. An overall method and procedure of the measurement by the solar simulator are discussed and proposed.
\end{abstract}

Copyright (C) 2015 Institute of Advanced Engineering and Science. All rights reserved.

\section{Corresponding Author:}

Y.M. Irwan,

Centre of Excellence for Renewable Energy,

School of Electrical System Engineering,

University Malaysia Perlis (UniMAP), Malaysia.

Email: irwanyusoff@unimap.edu.my

\section{INTRODUCTION}

Non-renewable energy is produced by sources that will be used up or will never be replenished in our lifetimes. Besides that, the issues with a power source and use are relevant not only to global warming, but also to such type of environmental concerns as air pollution, acid precipitation, ozone exhaustion, forest damage, and radioactive substance emissions. Several potential solutions have developed to avoid these types of influences, including energy conservation via enhanced electric power efficiency, a reduction in fossil fuel use and an increase in Eco-friendly power supplies. Many developed and the developing countries promote renewable energy applications to solve the issue of non-renewable energy and to protect the environment.

A renewable resource is a very easy task to take place of non-renewable energy. Electrical energy is generally generated by utilizing several kinds of renewable energy such as wind energy, solar energy, geothermal energy, biomass energy and tidal energy. Solar energy is famous among all renewable energy that is generally utilized in two techniques. The first technique is to apply it instantly for heating or perhaps cooling of water and air, while not using an advanced electric circuitry. The second technique is simply converted into electrical energy through the use of PV panel. Directly conversion process of solar radiation into electrical energy is considered the most convenient method of using solar energy. The benefits of utilizing the PV reaction to generate electrical energy consist of absolutely no production of pollutants during operation, silent and prolonged lifespan. 
The main environmental factor that affects the electrical efficiency and power output of PV panel are solar radiation and operating temperature $[1,2]$. When the PV panel absorbs excess solar radiation, the operating temperature of the PV panel will be increased. When the operating temperature of PV panel increase, the PV panel efficiency decreases and vice versa [3]. This is due that PV panel only $15 \%$ of sunlight energy converts into electrical energy with the rest converted to the heat energy. Hassan B.S. et al [4] carried out the excess photon energy is dissipated in the form of heat affect the performance of solar cells. Thus, cooling method of solar panel was designed in order to keep operating temperature stable and low. H.G. Teo [5] suggested that air cooling and water cooling are used to cool the PV panel to keep up lower operating temperature. This is because the temperature of PV panel without active cooling mechanism was high and PV cells can only achieve an efficiency of 8-9 \%. K. Tonui [6] described air cooling is preferred than the other cooling arrangements due to minimal use of material and low operating cost despite its poor thermo physical properties. It is can decrease the temperature of PV panel in order to enhance the electrical efficiency of PV panel.

The weather is always changing and as many scientists are hard to design ways to enhance the efficiency of PV panel. Thus, solar simulators are very helpful in a solar energy investigation. Solar simulators are a light source supplying illumination approximate to the natural sunlight. They are utilized for manipulating indoor of the various components and devices to assess, but often for the study PV cells, the cell characteristics and performance validation of components is achieved. The tests can be investigated by utilizing solar simulator at any time, continued for 24 hours a day, controlled for variation of temperature and other features of a common environment. Fu Qiang and Tong Nan [7] have proposed simulation model of PV cells is built to simulate environment situations under different lights and temperatures. The choice of an ideal light source to simulate sunlight and it's a real strength is the principal work with a design of solar simulator. In the background of solar simulation, many different of lamps have been suggested, and this can be listed as follows: halogen lamps, xenon arc lamps, argon arc lamp, mercury xenon lamp and so on.

Solar simulator consists of climate type 143 tungsten halogen $300 \mathrm{~W}$ lamps had been developed by NASA-Lewis laboratory, USA [8]. The infrared radiation generated by the lamps was reduced by utilizing diachronic reflectors. Natural solar radiation on the earth's surface was simulated by artificial light several decade years ago. E.J.G. Beeson [9]. P. Krusi [10] and S.P. Kenny [11] reported the multiple-lamp solar simulators consisted of 20, 21 and 28 CSI lamps with a rated power of 1000 Watts, respectively. A simple low-cost solar simulator for indoor testing using 14 quartz halogen lamps of $1000 \mathrm{~W}$ followed in 1985 [12]. The solar radiation is in the range of 400 and $1500 \mathrm{~W} / \mathrm{m}^{2} .45$ units of halogen lamps type CDX $300 \mathrm{~W}$ was built in a solar simulator [13], and a simulator constructed with 23 units of tungsten halogen lamps of $500 \mathrm{~W}$ [14]. The infrared radiation produced by the lamps was filtered out by using two exhaust fans.

The comparison of the performance of the PV panel with and without air cooling mechanism is the main focus of this investigation. The results of both PV panels are tested by using solar simulators. Hence, the next sections these analyses will be carried out.

\section{EQUIPMENT SETUP FOR SOLAR SIMULATOR TESTING}

Twenty units of halogen lamps with built in reflector were built in solar simulator. A steel metal support structure with the size is $183 \mathrm{~cm}$ by $183 \mathrm{~cm}$ by $183 \mathrm{~cm}$ is utilized to carry all the halogen lamps, which are arranged in an array as displayed in Figure 1.

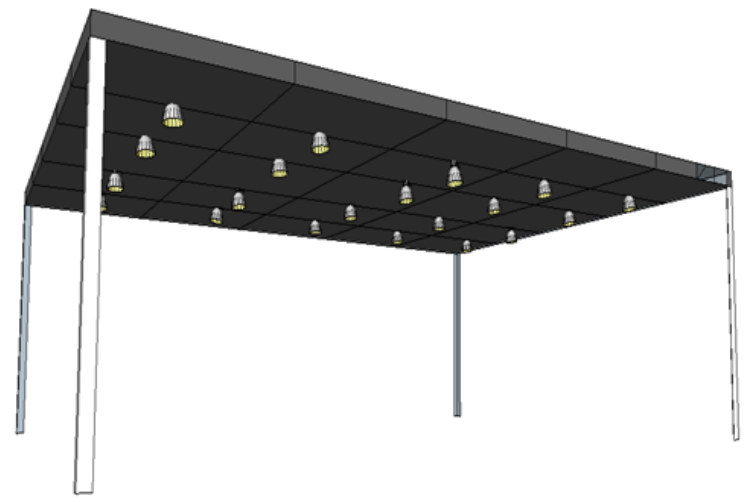

Figure 1. The fabrication solar simulator design 
The holder stand steel metal support structure can be adjusted independently. The distance between each center of halogen lamp is close to $32 \mathrm{~cm}$. The space distance between the PV panels and halogen lamps is approximately $67.3 \mathrm{~cm}, 82.5 \mathrm{~cm}, 95 \mathrm{~cm}$ and $119.38 \mathrm{~cm}$ for testing the different solar radiation, respectively.

The color temperature of the lamp is the temperature of an ideal black body radiator with the peak irradiance at the same wavelength as the test source. The selection lamps used in this fabrication are highefficiency lamps, with coiled-coil filament, giving white halogen light and manipulate at $230 \mathrm{~V}$, Philips Halogen $500 \mathrm{~W}$. Table 1 shows the specification of Philips Plus Line Halogen Lamp. The lifespan of the lamps is 2000 hours. However, its inexpensive and excellent light output, maintenance, and improved consistency [15] make it widely used as the infrared light source in multi-source solar simulators and the solar simulators with less spectrum requirements.

Table 1. Specifications Philips Plus Line Halogen Lamp.

\begin{tabular}{cc}
\hline Model & Specification \\
\hline Wattage & $500 \mathrm{~W}$ \\
Voltage & $230 \mathrm{~V}$ \\
Current & $2.17 \mathrm{~A}$ \\
Flux lamp & $9660 \mathrm{Lm}$ \\
Color temperature & $2900 \mathrm{~K}$ \\
Lifetime & $2000 \mathrm{hr}$ \\
Diameter & $12 \mathrm{~mm}$ \\
Length & $117.6 \mathrm{~mm}$ \\
\hline
\end{tabular}

In this investigation, two units of 50W Monocrystalline PV panels were utilized to convert solar energy into electrical energy. One of the PV panels is attached with DC brushless fans at the back surface of the panel and the other panel is a traditional PV as a reference panel as shown in Figure 2. TES solar power meter was used to measure the solar radiation of solar simulator. Four sets of average solar radiation were measured as 413,620, 821 and $1016 \mathrm{~W} / \mathrm{m}^{2}$. PROVA 200 solar module analyzer was used to measure the performance of both PV panels with and without air cooling mechanism.

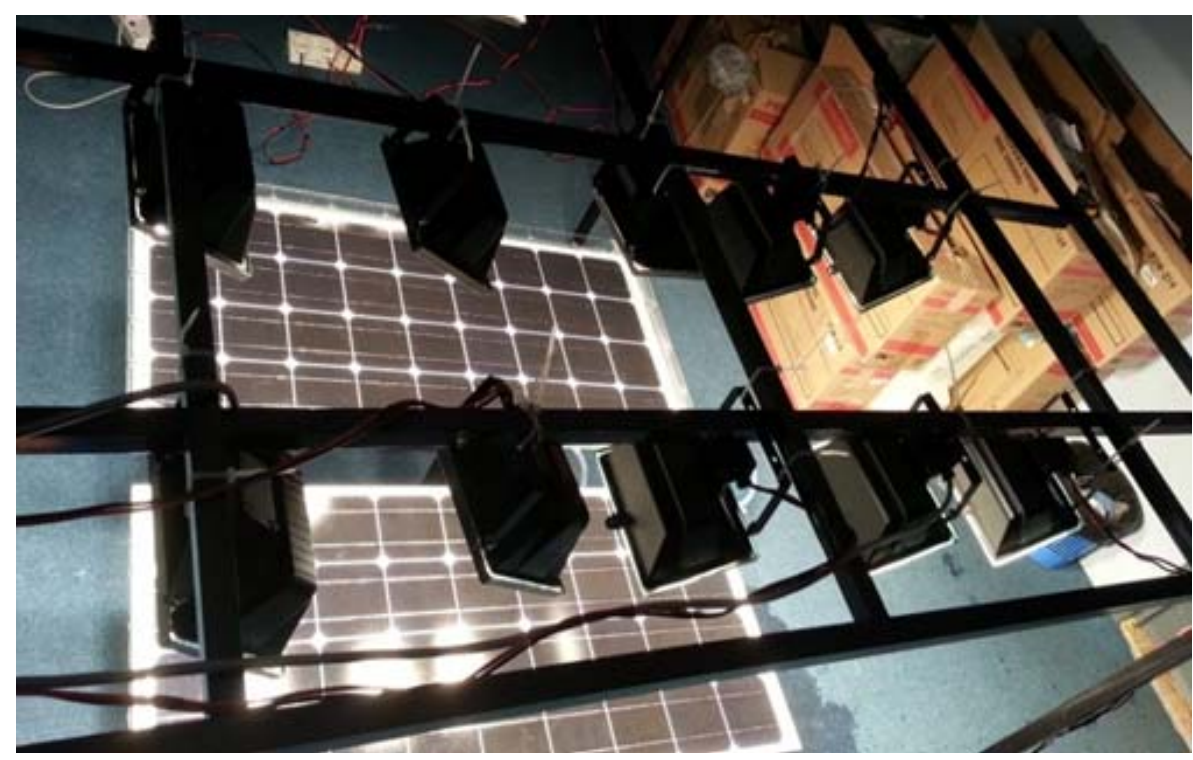

Figure 2. PV panel with and without cooling mechanism by using solar simulator

\section{RESULTS AND ANALYSIS}

The fabricated solar simulator is capable of generating repeatable ranges of solar radiation at any time any weather in the indoor test. Four sets of average solar radiation have been measured by using solar meter. Table 2 shows the distance between the PV panels and halogen lamps. 
Table2. Distance Between PV Panels And Halogen Lamp

\begin{tabular}{cc}
\hline Average Solar Radiation & Distance between PV panels and halogen lamps \\
\hline $413 \mathrm{~W} / \mathrm{m}^{2}$ & $119.38 \mathrm{~cm}$ \\
$620 \mathrm{~W} / \mathrm{m}^{2}$ & $95 \mathrm{~cm}$ \\
$821 \mathrm{~W} / \mathrm{m}^{2}$ & $82.5 \mathrm{~cm}$ \\
$1016 \mathrm{~W} / \mathrm{m}^{2}$ & $67.3 \mathrm{~cm}$ \\
\hline
\end{tabular}

Figure 3 shows the operating temperature of PV panel with and without air cooling mechanism at 413, 620, 821 and $1016 \mathrm{~W} / \mathrm{m}^{2}$, respectively. In the $413 \mathrm{~W} / \mathrm{m}^{2}$, the average operating temperature of PV panel with air cooling mechanism is $37.09{ }^{\circ} \mathrm{C}$. While the average operating temperature of PV panel reference is $39.65{ }^{\circ} \mathrm{C}$. Based on the results of both PV panels, it can be seen that the operating temperature of PV panel can be decreased is approximately $2.56{ }^{\circ} \mathrm{C}$ by using air cooling mechanism. On the other hand, the operating temperature of PV panel with air cooling mechanism is also lower than the PV panel reference at 620 and $821 \mathrm{~W} / \mathrm{m}^{2}$. By using air cooling mechanism, the PV panel can be decreased $2.41{ }^{\circ} \mathrm{C}$ and $2.19{ }^{\circ} \mathrm{C}$ compared to $\mathrm{PV}$ panel reference in the $620 \mathrm{~W} / \mathrm{m}^{2}$ and $821 \mathrm{~W} / \mathrm{m}^{2}$, respectively.

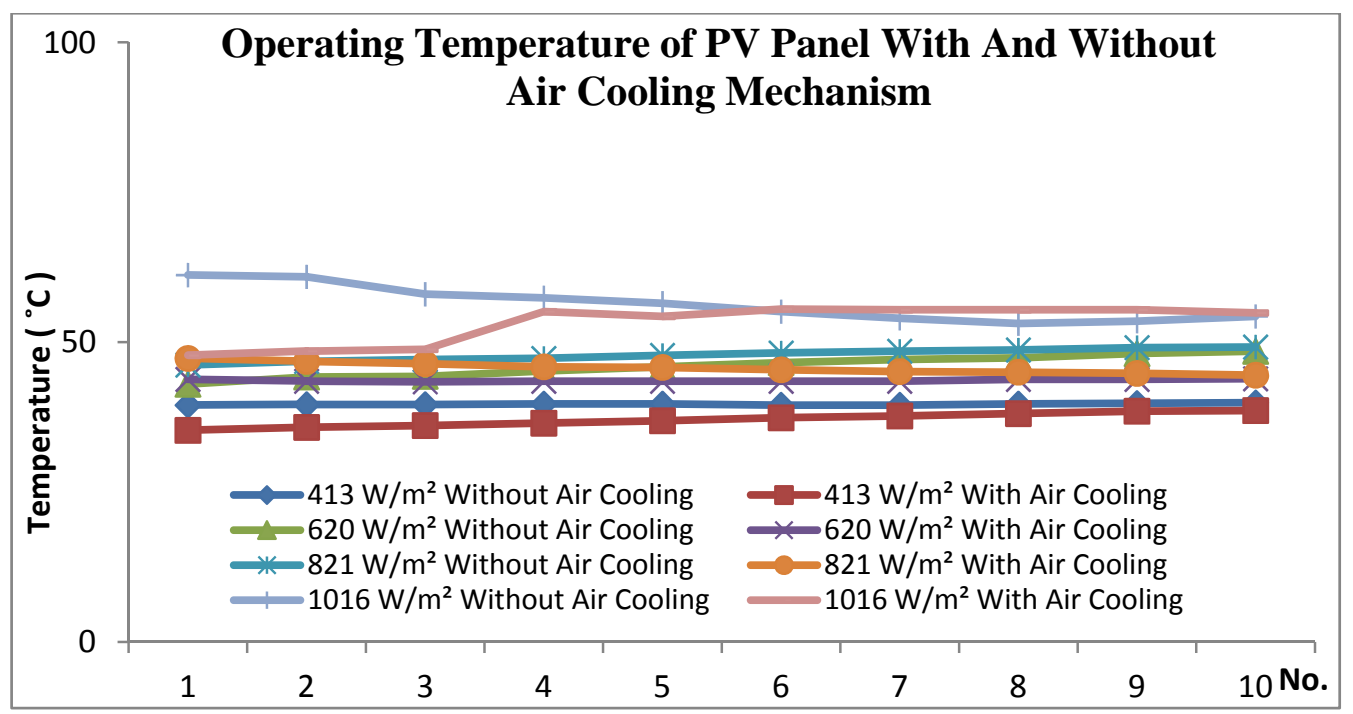

Figure 3. Operating temperature of PV panel with and without air cooling mechanism

Besides that, the average operating temperature of PV panel with air cooling mechanism is $53.11{ }^{\circ} \mathrm{C}$ and average operating temperature of PV panel reference is $56.4{ }^{\circ} \mathrm{C}$ for the solar radiation is in $1016 \mathrm{~W} / \mathrm{m}^{2}$. In the comparison result of both PV panels in the $1016 \mathrm{~W} / \mathrm{m}^{2}$, the decrement of the operating temperature of PV panel is $3.29{ }^{\circ} \mathrm{C}$ by using air cooling mechanism. From the figure above, it can be analytically that the PV panel suffers from the high operating temperature under high condition of solar radiation. The higher operating temperature of PV panel is a negative effect on the electrical efficiency of PV panel. The operating temperature of PV panel can be decreased by using DC brushless fans. Thus, the air circulation by forcing flow in the channel reduces the operating temperature of PV panel by at least $2.19{ }^{\circ} \mathrm{C}$. Infield et al. [16] carried out the temperature of PV panel can be reduced by flowing air between PV panel and the double glass wall for spacing heating.

Figure 4 displays the maximum voltage of PV panel with and without air cooling mechanism. In the $413 \mathrm{~W} / \mathrm{m}^{2}$, the average maximum voltage of PV panel with air cooling mechanism is $16.72 \mathrm{~V}$ while $15.97 \mathrm{~V}$ is the average maximum voltage for PV panel reference. The increment of maximum voltage is approximately $4.49 \%$ by using DC brushless fans. Besides that, $16.71 \mathrm{~V}, 15.74 \mathrm{~V}$ and $15.35 \mathrm{~V}$ are the average maximum voltage for the PV panel with air cooling mechanism in the $620 \mathrm{~W} / \mathrm{m}^{2}, 821 \mathrm{~W} / \mathrm{m}^{2}$ and 1016 $\mathrm{W} / \mathrm{m}^{2}$, respectively. Whereas, the average maximum voltage of the PV panel reference in the $620 \mathrm{~W} / \mathrm{m}^{2}, 821$ $\mathrm{W} / \mathrm{m}^{2}$ and $1016 \mathrm{~W} / \mathrm{m}^{2}$ is $15.14 \mathrm{~V}, 14.89 \mathrm{~V}$ and $14.70 \mathrm{~V}$, respectively. The comparison between PV panel with and without air cooling mechanism carried out that the maximum voltage can be increased by using DC brushless fans. The increment of maximum voltage is $9.4 \%, 5.4 \%$ and $4.23 \%$ in the $620 \mathrm{~W} / \mathrm{m}^{2}, 821 \mathrm{~W} / \mathrm{m}^{2}$ and $1016 \mathrm{~W} / \mathrm{m}^{2}$, respectively. 


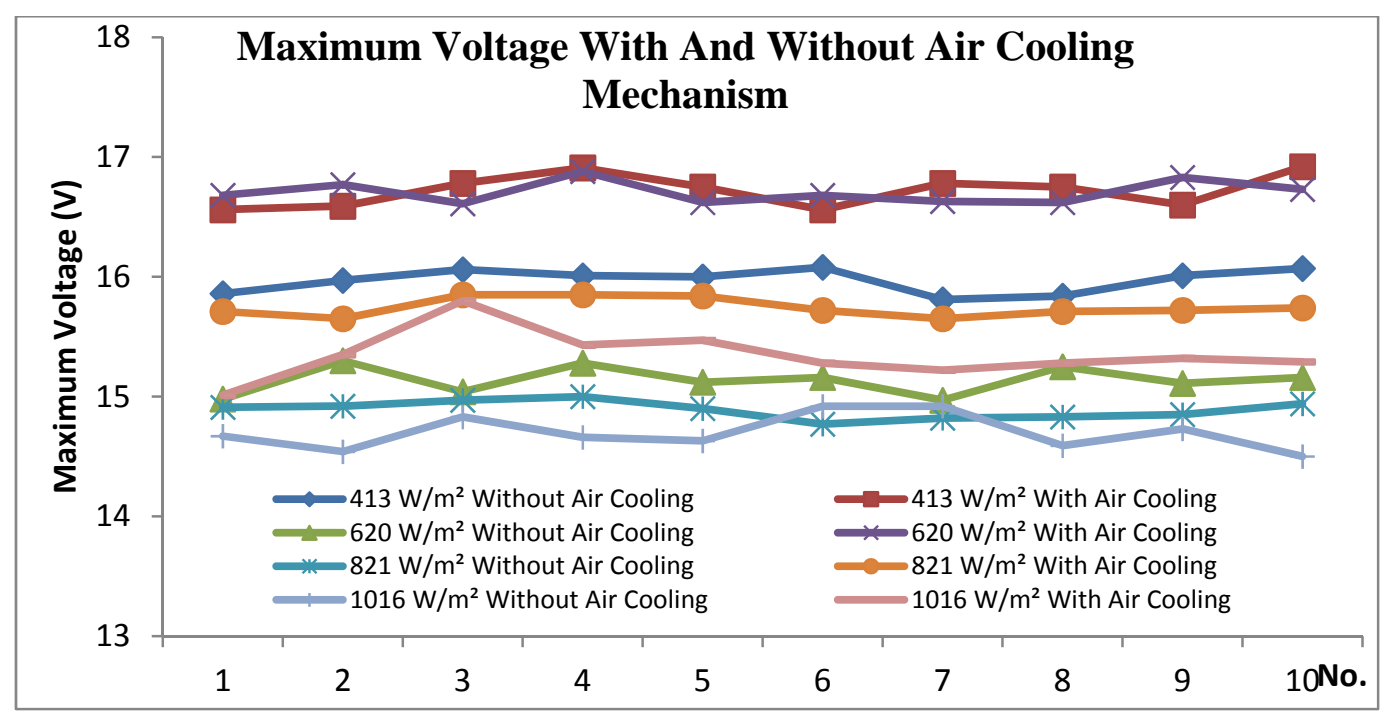

Figure 4. Maximum voltage of PV panel with and without air cooling mechanism

When the solar radiation is increasing, both open circuit voltage and short circuit current will be increased. When the solar radiation increases as the operating temperature also increased. But, the operating temperature is another main factor to determine the performance of PV panel. When the operating temperature is increased, the rate of photon generation increases and reverse saturation current increases rapidly. This condition cause the band gap of semiconductor will be reduced and lead to current slightly changes and major change in voltage. Thus, the DC brushless fans were used to cool down the operating temperature in order to enhance performance of PV panel. Triganagnostopoulod et al [17] examined that PV cooling can be increased the performance of PV panels and increasing the total efficiency of the whole systems.

Figure 5 presents the variety of maximum current of PV panel with and without an air cooling mechanism in different fixed solar radiation. The variation of maximum current of PV panel with air cooling mechanism and PV panel reference were tested in the $413 \mathrm{~W} / \mathrm{m}^{2}, 620 \mathrm{~W} / \mathrm{m}^{2}, 821 \mathrm{~W} / \mathrm{m}^{2}$ and $1016 \mathrm{~W} / \mathrm{m}^{2}$, respectively. The average maximum current of PV panel with air cooling mechanism is $1.15 \mathrm{~A}$ while the average maximum current of PV panel reference is 1.12 A in the $413 \mathrm{~W} / \mathrm{m}^{2}$. By using air cooling mechanism, the maximum current of PV panel can be increased $2.6 \%$. In the $620 \mathrm{~W} / \mathrm{m}^{2}$ and $821 \mathrm{~W} / \mathrm{m}^{2}$, the average maximum current that generated by a PV panel with air cooling mechanism is higher than the PV panel reference.

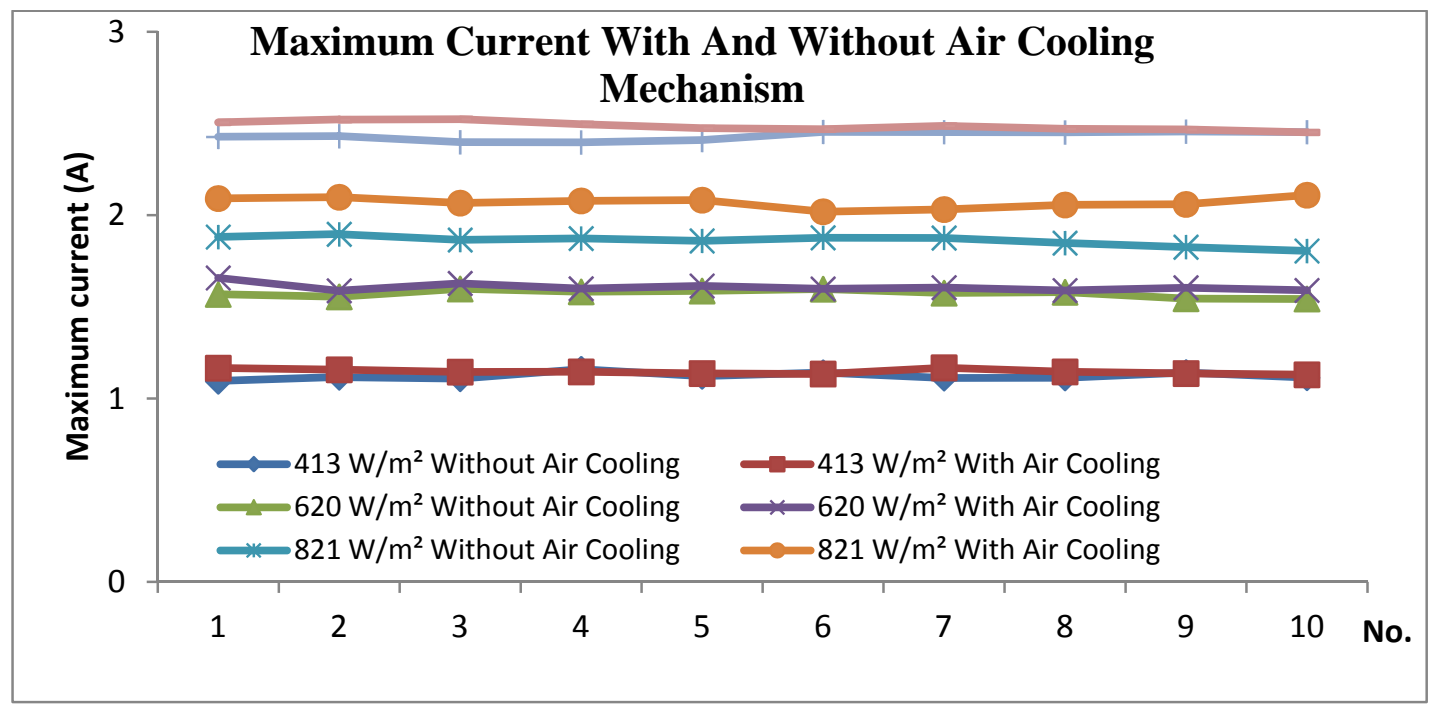

Figure 5. Maximum current of PV panel with and without air cooling mechanism 
The average maximum current of PV panel with air cooling mechanism is $1.61 \mathrm{~A}$ and $2.07 \mathrm{~A}$ for $620 \mathrm{~W} / \mathrm{m}^{2}$ and $821 \mathrm{~W} / \mathrm{m}^{2}$, respectively. The percentage increment of maximum current is $2.48 \%$ and $10.1 \%$, respectively, compared to PV panel reference. Besides that, the average maximum current of the PV panel with air cooling mechanism is 2.49 A while the average maximum current of PV panel reference is $2.43 \mathrm{~A}$ for the $1016 \mathrm{~W} / \mathrm{m}^{2}$ solar radiation. As can be seen from the figure, the percentage increment in maximum current of PV panel is $2.41 \%$ by using DC brushless fans. It can be observed that the increment of solar radiation as the short circuit current of PV panel increases. But, the increment of the PV panel operating temperature, the short circuit current is slightly decreased. In order to enhance the electrical efficiency of PV panel, the surface of PV panel must always keep at a lower temperature. It can be pointed out that the maximum current of PV panel can be increased by using air cooling mechanism.

Figure 6 illustrates the variation of maximum power of PV panel with and without air cooling mechanism in different fixed solar radiation. The variation of maximum power of PV panel with air cooling mechanism and PV panel reference were tested in the $413 \mathrm{~W} / \mathrm{m}^{2}, 620 \mathrm{~W} / \mathrm{m}^{2}, 821 \mathrm{~W} / \mathrm{m}^{2}$ and $1016 \mathrm{~W} / \mathrm{m}^{2}$, respectively. In the $413 \mathrm{~W} / \mathrm{m}^{2}$, the average maximum power of PV panel with air cooling mechanism is 19.17 $\mathrm{W}$ while the average maximum power that generated by PV panel reference is $17.93 \mathrm{~W}$. In the comparison between both PV panels, the PV panel with air cooling mechanism can be generated more power output compared to PV panel reference. It is clear that the increment of the maximum power of PV panel is approximately $6.47 \%$ when apply DC brushless fans at the backside of PV panel. On the other hand, the average maximum power of PV panel with air cooling mechanism is $26.85 \mathrm{~W}$ and $32.58 \mathrm{~W}$ in the $620 \mathrm{~W} / \mathrm{m}^{2}$ and $821 \mathrm{~W} / \mathrm{m}^{2}$, respectively. While the average maximum power of PV panel reference in the $620 \mathrm{~W} / \mathrm{m}^{2}$ and $821 \mathrm{~W} / \mathrm{m}^{2}$, is $23.81 \mathrm{~W}$ and $27.71 \mathrm{~W}$ respectively.

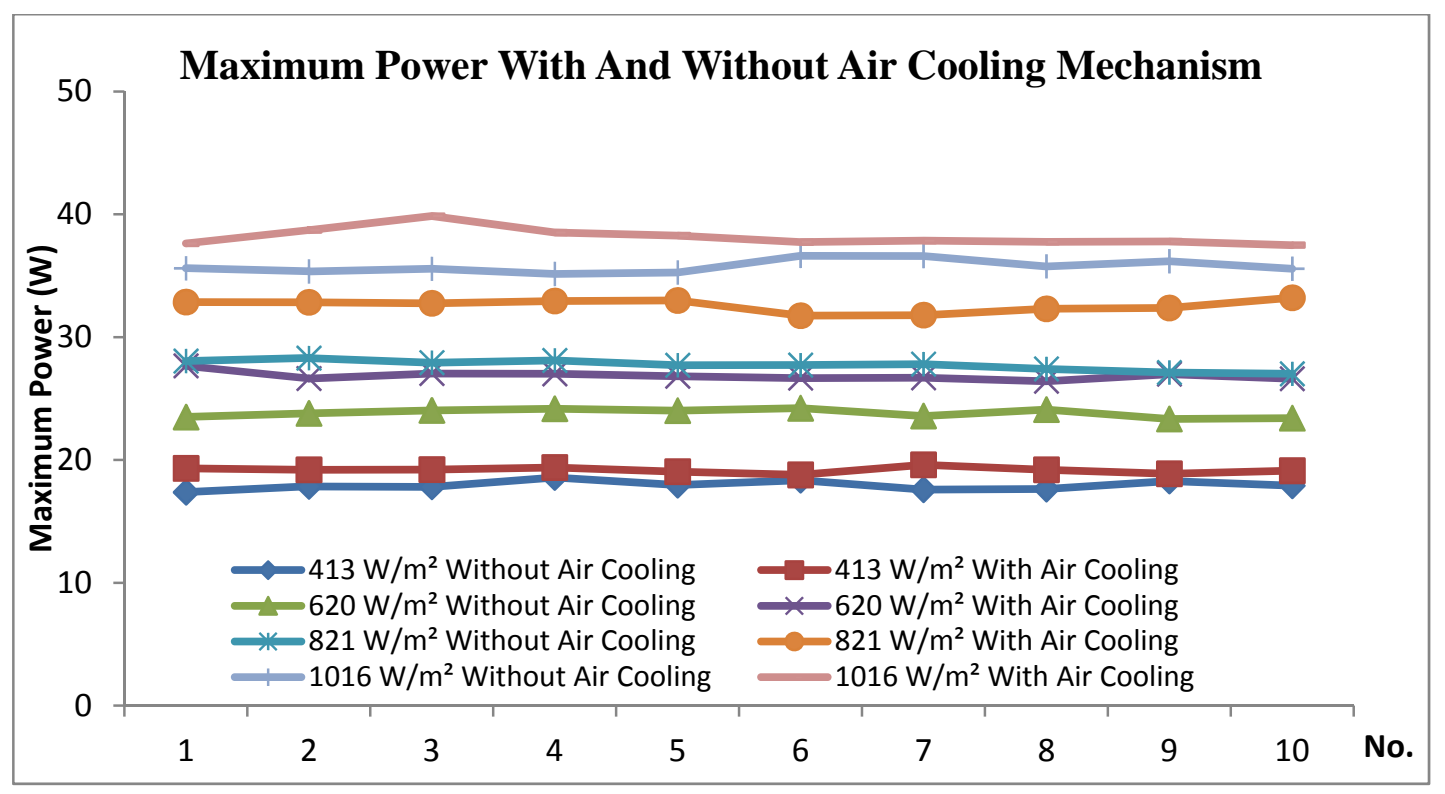

Figure 6. The variation of maximum power of PV panel with and without air cooling mechanism.

It can be seen that the maximum power of PV panel can be increased by using air cooling mechanism. Also, it is obvious that the percentage of increment in the maximum power of PV panel is $11.32 \%$ and $14.95 \%$ for the $620 \mathrm{~W} / \mathrm{m}^{2}$ and $821 \mathrm{~W} / \mathrm{m}^{2}$, respectively. Besides that, the average maximum power of PV panel with air cooling mechanism is $38.16 \mathrm{~W}$ and the average maximum power of PV panel reference is $35.76 \mathrm{~W}$ in the $1016 \mathrm{~W} / \mathrm{m}^{2}$. It can be observed that the average maximum power of PV panel with air cooling mechanism is higher than the PV panel reference. The increment of the maximum power of PV panel is $6.29 \%$ by using DC brushless fans. This is due that DC brushless fans can reduce the operating temperature of PV panel. It can be concluded that the performance of PV panel decreases as the operating temperature increases. Therefore, the cooling mechanism is important to cool down the operating temperature of PV panel in order to increase the electrical efficiency of PV panel. Chow et al. [18] have developed modeling of air-cooled PV panels. They found that the overall electrical efficiency of the PV / T system in the year is around $10.2 \%$. 


\section{CONCLUSION}

The design and fabrication of the solar simulator with halogen lamps has been successfully determined in this experiment. The solar radiation of the solar simulator system is higher repeatable at any time. This solar simulator system can be able to test the performance of PV panel within the size of test area. The main purpose of solar simulator is to analysis the performance of PV panel with and without an air cooling mechanism in indoor test. The solar radiation and operating temperature are the main factors that affect the electrical efficiency of PV panel. The increment in operating temperature of PV panel due to higher solar radiation leads to reduce the electrical efficiency and the degradation of PV panel. When the solar radiation decreased, the maximum power output that generated by PV panels also decreased. This is because of less availability of photons of semiconductor cells. The air cooling mechanism is designed and constructed to keep the panel within certain temperatures. In the comparison between performance of PV panels with and without air cooling mechanism, air cooling setup has decreased due to thermal effects and increases the power output. Besides, the operating temperature of PV panel with air cooling mechanism is lower than the PV panel reference. The experimental results mentioned that the decrement of operating temperature is around $2-3{ }^{\circ} \mathrm{C}$ increase the power output of the PV panel with air cooling mechanism by $6-14 \%$. The increment of power output will have a significant contribution to the PV system applications.

\section{ACKNOWLEDGEMENTS}

The authors thank the Centre of Excellence for Renewable Energy (CERE), University Malaysia Perlis (UniMAP) in Kangar, Perlis for providing all data used in this study.

\section{REFERENCES}

[1] Koumi N.S., Njomo D., and Moungnutou M.I., "Comparison of Predictive Models for Photovoltaic Module Performance under Tropical Climate”, TELKOMNIKA Indonesian Journal of Electrical Engineering, Vol. 10, No.2, June 2012, pp. 245-256.

[2] M. Abdulkadir, A.S. Samosir and A.H.M. Yatim, "Modeling and Simulation of a Solar Photovoltaic System, Its Dynamics and Transient Characteristics in LABVIEW”, International Journal of Power Electronics and Drive System (IJPEDS), Vol. 3, N0. 2, June 2013, pp. 185-192.

[3] W.Z. Leow, Y.M. Irwan, M. Irwanto, N. Gomesh and I. Safwati, "PIC18F4550 Controlled Solar Panel Cooling System Using DC Hybrid”, Journal of Scientific Research \& Reports, 3(21): 2801-2816, 2014.

[4] Hassane B.S., Ben M.D. and Helmaoui A., "Theoretical Study of Multiple Solar Cells System as a Function of Temperature”, TELKOMNIKA Indonesian Journal of Electrical Engineering, Vol. 12, No. 7, July 2014, pp. 49284933.

[5] Teo H.G., Lee P.S., Hawlader M.N.A., “An active cooling system for PV modules”, Applied Energy.2012; 90: 309315.

[6] J.K. Tonui, Y. Tripanagnostopoulos, "Air-cooled PV/T solar collectors with low cost performance improvements", Solar Energy, 2007, pp. 498-511.

[7] Fu Qiang and Tong Nan, “A Strategy Research on MPPT Technique in Photovoltaic Power Generation System”, TELKOMNIKA Indonesian Journal of Electrical Engineering, Vol. 11, No. 12, December 2013, pp. 7627-7633.

[8] Yass, K., Curtis, H.B., 1974, “Low Cost Air Mass 2 Solar Simulator”, NASA Technical Memorandum, NASA TM $\mathrm{X}-3059$.

[9] Beeson, E.J.G., "The CSI lamp as a source of radiation for solar simulation”, Lighting Research \& Technology, 10(3), 164-166 (1978).

[10] Krusi P., Schmid R., “The CSI 1000W lamp as a source for solar radiation simulation”, Solar Energy, 30 (5), 455 462 (1983).

[11] Kenney S.P, and Davidson J.H., "Design of a Multiple-Lamp Large-Scale Solar Simulator”, ASME Journal of Solar Energy Engineering, 116(11), 200-205 (1994).

[12] Garg, H.P., and Shukla, A.R., 1985, "Development of Simple Low-Cost Solar Simulator for Indoor Collector Testing, New Delhi, India”, Applied Energy, 21, pp. 43-54.

[13] Supranto, Sopian, K., Daud, W.R.W., Othman, M.Y., and Yatim, B., "Design and Construction of Low Cost Solar Simulator”, World Renewable Energy Congress V, (Pergamon Press, Oxford, 1999), pp. 121-125.

[14] Nazari, A.B., 2007, "Performance Evaluation of a Double-Pass Photovoltaic-Thermal Solar Collector with Compound Parabolic Concentrators and Fins”, PhD Thesis, UKM.

[15] E.J.G. Beeson, “The CSI Lamp as a Source of Radiation for Solar Simulation”, Lighting Research and Technology, 10(1978), pp. 164-166. 
[16] Infield D, Mei L, and Eicker U, “Thermal Performance estimation of Ventilated PV Facades”, Solar Energy 2004; 76: 93-8.

[17] J.K. Tonui, Y. Tripanagnostopoulos, "Performance Improvement of PV/T Solar Collectors with Natural Air Flow Operation”, Solar Energy, 2008, pp. 1-2.

[18] Chow T.T., “A review on Photovoltaic/Thermal Hybrid Solar Technology”, Applied Energy 2010; 87: 365-79. 